\title{
DAILY MOBILITY OF THE ELDERLY: AN EXAMPLE FROM ŁÓDŹ, POLAND
}

Marta Borowska-Stefańska, Szymon Wiśniewski, Michał Kowalski

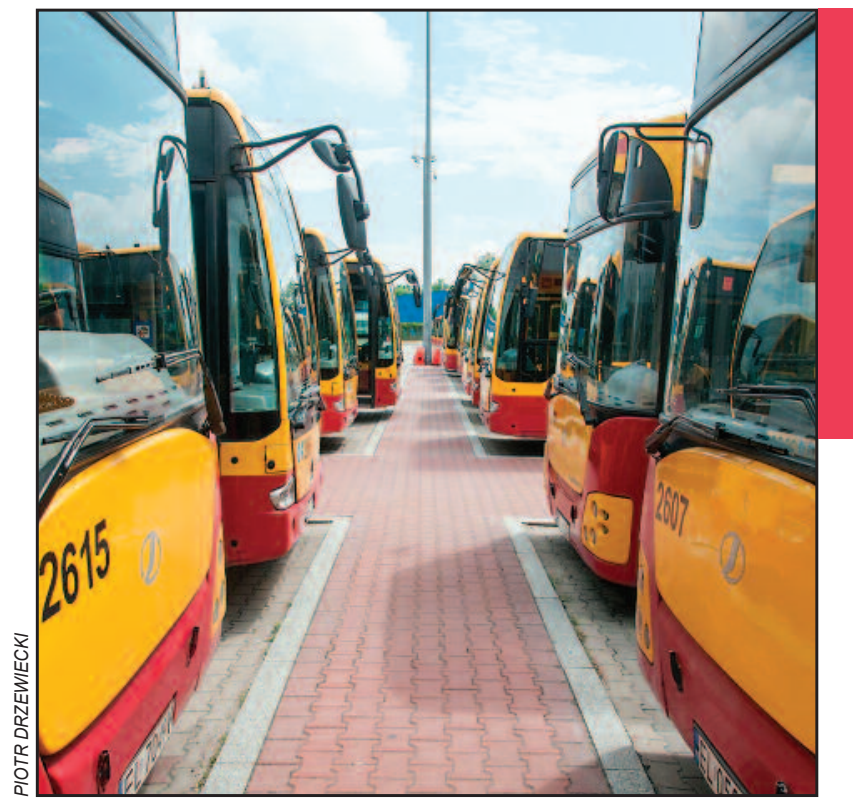

Figure caption Public transport in Łódź. 
DOI: https://doi.org/10.3986/AGS.7490

UDC: $911.375: 331.556-053.9(438)$

COBISS: 1.01

Marta Borowska-Stefańska ${ }^{1}$, Szymon Wiśniewski $^{1}$, Michał Kowalski ${ }^{1}$

\section{Daily mobility of the elderly: An example from Łódź, Poland}

ABSTRACT: Recently, numerous countries have been facing the issue of population ageing, which poses a formidable challenge for many sectors, including transportation. Alas, there are no detailed or insightful studies that involve the analysis of the elderly, which is why the authors of this paper decided to research the issue to determine which features of mobility are common among senior citizens (aged 60+). In our study, we focused on Bałuty, a district located in Łódź. The applied research tool was an interview questionnaire which consisted of eight questions. Since transportation is a fundamental human need, maintenance of the mobility of the elderly at an acceptable level is crucial as it directly impacts the quality of their life. What is more, a change of motivation and mode of transport is recommended for this age group.

KEY WORDS: daily mobility, the elderly, questionnaire, Lodz, Poland

\section{Dnevna mobilnost starejših: primer Lodža na Poljskem}

POVZETEK: V zadnjem času se številne države spopadajo s problemom staranja prebivalstva, ki mnoge sektorje, tudi promet, postavlja pred velik izziv. Kljub temu do zdaj še ni bilo opravljenih podrobnih študij, ki bi analizirale mobilnost starejših. Avtorji članka so se zato odločili proučiti glavne značilnosti mobilnosti pri posameznikih, starejših od 65 let, ki živijo v okrožju Baluty v poljskem mestu Lodž. V raziskavi so uporabili anketo $\mathrm{z}$ vprašalnikom, sestavljenim iz osmih vprašanj. Ker je prevoz temeljna človekova pravica, je ključno ohranjati mobilnost starejših na zadovoljivi ravni, saj to neposredno vpliva na kakovost njihovega življenja. Poleg tega je za to starostno skupino priporočljivo, da spremenijo motivacijo in način prevoza.

KLJUČNE BESEDE: dnevna mobilnost, starejši, vprašalnik, Lodž, Poljska

The paper was submitted for publication on July $2^{\text {nd }}, 2019$.

Uredništvo je prejelo prispevek 2. julija 2019.

\footnotetext{
${ }^{1}$ University of Lodz, Faculty of Geographical Sciences, Lodz, Poland marta.borowska@geo.uni.lodz.pl (https://orcid.org/0000-0003-2448-4778), szymon.wisniewski@geo.uni.lodz.pl (https://orcid.org/0000-0001-5488-5949), michal.kowalski@geo.uni.lodz.pl (https://orcid.org/0000-0001-7082-5161)
} 


\section{Introduction}

Recently, numerous countries have been facing the issue of population ageing, which poses a formidable challenge for many sectors, including transportation (Hildebrand 2003; Coughlin 2009; Kim 2011; Haustein and Siren 2015; Saboor et al. 2015; Stjernborg, Wretstrand and Tesfahuney 2015), since transport is one of people's fundamental needs at various stages of their life and is inseparably connected with independence, autonomy and a good quality of life (Carp 1988; Kaplan 1995; Tacken 1998; Metz 2000; Dickerson et al. 2007; Hjorthol, Levin and Sirén 2010; Li et al. 2012). Changes due to aging populations bring new challenges related to the provision of transportation services, mainly due to the fact that the travel habits and needs of the elderly differ substantially from those of other social groups (Rosenbloom 2001; Alsnih and Hensher 2003). Existing studies indicate that elderliness is directly related to a reduction in mobility (Hanson 1977; Alsnih and Hensher 2003; Tiitta 2003) and that senior citizens are more accepting of the fact that they may need to use modes of transport other than the car and to travel noticeably shorter distances (Schwanen, Dijst and Dieleman 2001; Rosenbloom 2004; Páez et al. 2007; Mercado and Páez 2009; Roorda et al. 2010). Despite certain common effects regarding age-related journeys, it is clearly emphasised in the literature that the mobility of senior citizens is not of a homogeneous nature (Schwanen and Páez 2010). The studies conducted by Schwanen, Dijst and Dieleman (2001), Páez et al. (2007), Roorda et al. (2010) indicate that there are considerable differences among the elderly in terms of frequency of travel, distance and means of transport. Factors determining these differences include social status, their financial situation, current health condition and mobility, lifestyle, and motivations at various stages of senectitude (Kałuża-Kopias 2014; Raczyńska-Buława 2017). The wide diversity of mobility patterns observed among the elderly poses an complex problem and has become a significant challenge for transportation planning and policy (Metz 2003; Páez et al. 2007; Schwanen and Páez 2010), This is particularly noticeable in cities where the process of population ageing is exceptionally dynamic and is, at the same time, related to the phenomenon of depopulation, as illustrated by the example of Łódź used here. Alas, there are no detailed or insightful studies that involve the analysis of the elderly, which is why the authors of this paper decided to research the issue to determine which features of mobility are common among senior citizens (aged 60+).

In our study, we focused on Bałuty, a district located in Łódź. In line with the perception of daily mobility presented in the literature (Bartosiewicz and Pielesiak 2014), the research described in this article concentrates on the totality of daily and recurring trips taken. Since the target group is the elderly, however, the set of analysed trip motivations was expanded and adjusted to the specificity of this individual social group. In this case, »dailiness « of mobility is not perceived literally as a feature which determines that trips must be taken on a daily basis, but as a characteristic indicating that such trips are, by assumption, quite common and frequent, and thus, recurring. The mobility of the elderly was studied in terms of differences in trip destinations and frequency, preferred modes of transport, length and duration of trips, time of their occurrence, and types of spatial mobility limitations. Management of an urban transport system in a manner that meets the needs of local residents must directly entail studies of their daily transport behaviours (including spatial mobility). Moreover, in the face of dynamic population ageing, it is also vital to conduct activities that promote mobility for the benefit of the elderly and their quality of life.

\section{Study area and methods}

Łódź, one of the largest Polish cities, was selected for the purposes of this study to illustrate the daily mobility behaviours of senior citizens, and this was by no means an accidental choice. Having analysed the 2016 data obtained from the Central Statistical Office (2019), the authors determined that the issue of population ageing afflicts all voivodeship capitals in Poland, and yet, the situation is worst in Łódź, which is interesting not only since its population is ageing, but also because it is in decline. These processes can be observed elsewhere in cities of the central and eastern EU (e.g., eastern parts of Germany - Magdeburg, Halle, and Romania - Arad) and some peripheral areas of Western Europe (e.g., Southern Italy, Northern England, and Northern Scandinavia) (Labus 2013). Łódź was chosen as a case study and an example of a city that is both »shrinking " and ageing at the same time, as, in all probability, the habits of its elderly citizens regarding the differentiation of trip destinations and frequency, preferred modes of transport, and length and duration of trips will be similar to other urban units of this kind. Łódź is classified among those 
cities whose situation is most difficult, i.e., their authorities must focus on redefining and renewing directions of development, including the sphere of transportation. Within the borders of Łódź, the percentage of people aged 60 or more has already exceeded $30 \%$, and of those who are 65 and above amounts to $21 \%$. Having conducted our questionnaire survey, we selected Bałuty (Figure 1).

An analysis of the percentage of older adults in individual districts reveals that by 2016, markedly the largest percentage of inhabitants aged 60 and above could be found in the Bałuty district (34.5\%) (BorowskaStefańska and Wiśniewski 2019). That is why the district in which the most elderly people live has just been selected for research.

The process of population ageing in Łódź stems from both the slowing growth rate of the young population and the relatively rapid growth rate of the older population, as ageing takes place both at the base of the population pyramid and at its top. It is worth stressing that of all Poland's provincial cities, the ageing demographic process in the area in question is at its greatest, which is why it is so important to carry out research into this particular group of inhabitants here.

As of 2016 the district of Łódź-Bałuty was populated by over 65,000 people, $63 \%$ of whom were women (Central Statistical Office 2019).

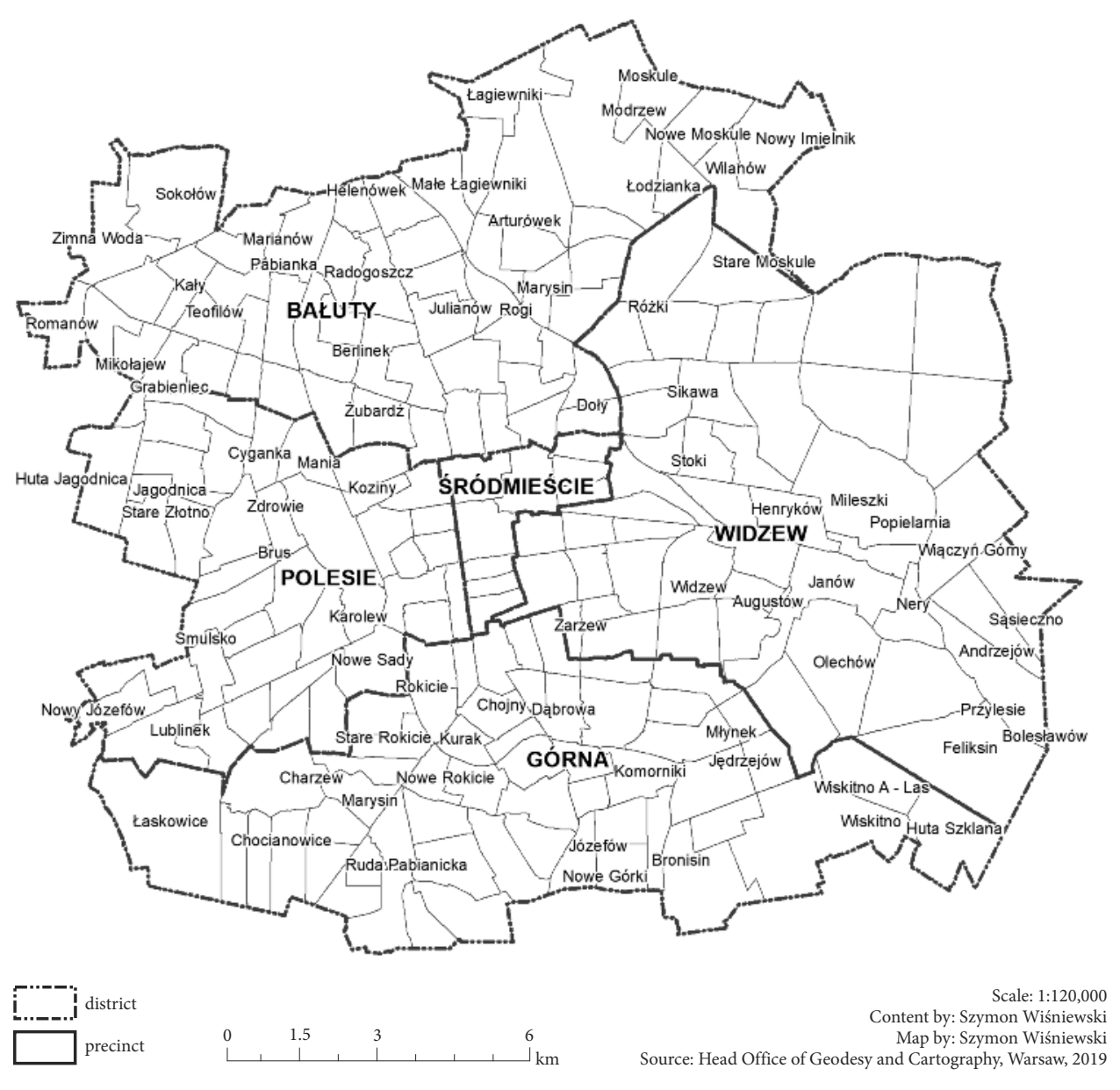

Figure 1: The division of Łódż into individual districts. 
As for employment-population ratios, $13.7 \%$ of Łódź-Bałuty's population are in the pre-working economic age group, which is lower than that for the overall city (about 14.3\%). In turn, $58.3 \%$ are of working age (compared to $59.9 \%$ for Łódź as a whole). The remaining $28 \%$ are of post-working age (25.8\% for Łódź overall). Bałuty's situation would appear to be particularly unfavorable, i.e. a small young population accompanied by a very large older population.

The demographic dependency ratio calculated for the analyzed district is over $71 \%$, which is higher than the value for the city as a whole (nearly 67\%). The ratio of post-working age inhabitants per 100 inhabitants of pre-working age comes to a staggering 205 in the analyzed area, compared to 181 for the whole of Łódź. The process of population ageing in Bałuty is clearly more visible than in the other districts (Central Statistical Office 2019).

On the basis of the presented data it may be concluded that the population of Bałuty is ageing, as further indicated by the population pyramid (Figure 2). It is of a regressive character, indicating that reproduction is at a level which does not ensure generational renewal, which is the case in the whole of the city (although the process is even more pronounced in Bałuty). The pyramid extends in its upper part while it narrows at the bottom (illustrating the decline in the number of children and teenagers, i.e. inhabitants under 20). These changes are characteristic of the long-term transformations in the number of inhabitants in all districts of Łódź.

The applied research tool was an interview questionnaire which consisted of eight questions regarding private car ownership (question one), the availability of a private car to the household (question two), the frequency of trips (question three) related to professional activity, visiting public offices and institutions, religious purposes, everyday (grocery) shopping, meeting friends/relatives, seeking medical assistance, participating in cultural events and entertainment, using services provided by hairdressers and beauticians, and attending meetings, classes and events organised by the 3rd age university, day care centres or senior citizen clubs. The respondents were to determine whether they are engaged in such types of daily mobility, and if so, they were also asked to specify whether such trips were taken on a daily basis, several times a week or a month, once a month, or no such trips had been made the previous month. The

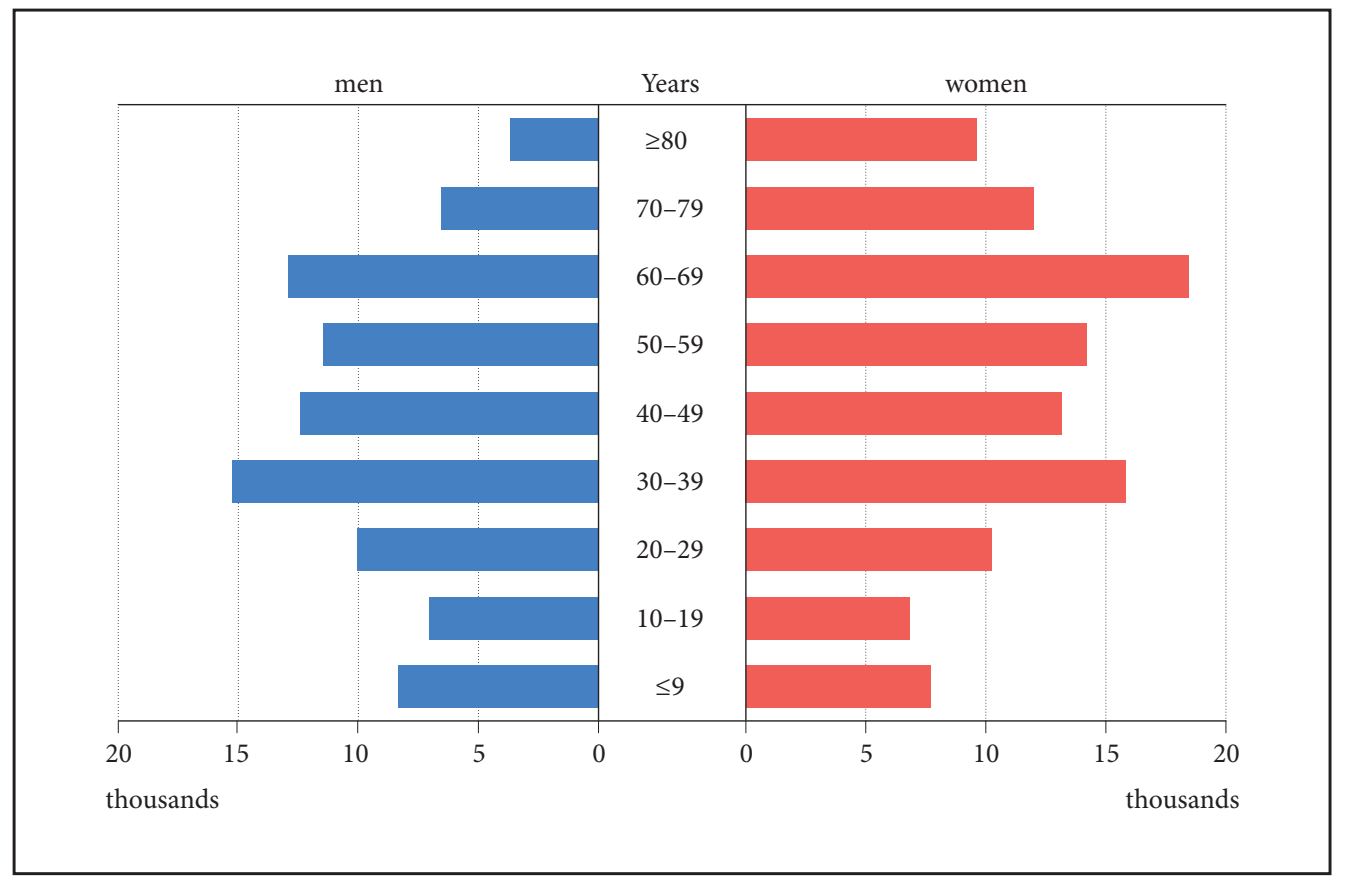

Figure 2: Population pyramid of Bałuty in 2017. 
next (question fourth) question focused on the most popular modes of transport used to carry out the aforementioned tasks (the list of available options included: private car owned either by the respondent or by any relative/neighbour, bicycle, taxi, public bus or tram, train, plane, going on foot, coach, or buses provided by shopping centres - the respondents could choose more than one option if their trip involved stops or changes). In the fifth question (question five), those surveyed were asked to specify the distance they covered to reach the destinations they had selected earlier in the questionnaire (this referred to a single trip, and the following distance ranges were provided: up to $400 \mathrm{~m}, 401-800 \mathrm{~m}, 801-1200 \mathrm{~m}, 1201-1600 \mathrm{~m}$, 1601-2000 m, and $>2000 \mathrm{~m}$ ). Another question (question six) focused on the average one-way travel time required to complete the intended tasks (the options included: up to $5 \mathrm{~min}, 5-10 \mathrm{~min}, 11-15 \mathrm{~min}, 16-20 \mathrm{~min}$, 21-25 $\mathrm{min}$, and $>25 \mathrm{~min}$ ). In question No. 7 (question seven), the respondent was to indicate how much time they needed to fulfil the selected tasks (with a choice of up to $15 \mathrm{~min}, 15-30 \mathrm{~min}, 31-60 \mathrm{~min}$, and $>1 \mathrm{hr}$ ). The last question (question eight) concerned the limitations of respondents' mobility. If there were any, the surveyed were asked to specify their nature (a semi-open question). These are all crucial constituents of mobility in terms of transport planning and policy. The final part of the questionnaire was the respondent's particulars.

It was elaborated on by the applicants on the basis of works by El-Telbani (1993), Taylor (1999), Wyszomirski (2008), Komornicki (2011), Sierpiński (2012), and Model of sustainable public transport in Łódź (Model zrównoważonego transportu zbiorowego w Łodzi 2020+,2019).

Personal interviewing techniques were used to carry out the research, using computer assisted personal interviewing (CAPI) or via a mobile device (MOBI). Both CAPI and MOBI are quantitative in character and involve direct communication between the interviewer and the respondent. They involve conducting a short interview during which the interviewer uses a dedicated system which displays questions on the screen of the mobile device used. The responses which are given and ticked in the system are recorded on an ongoing basis in the form of an electronic set of data. A questionnaire composed of a list of questions grouped into thematic sections was used as a research tool to structure and standardize the interviews.

The research was conducted among 400 inhabitants of the Bałuty district aged 60 and over as of November/December 2018 and concerned their daily mobility in the previous four-week period. In order to increase data reliability and gain a fuller picture of their mobility in the analyzed part of the city, the structure of the research sample took into account all the main administrative districts of Bałuty, i.e. BałutyZachodnie, Bałuty-Centrum, Bałuty-Doły, Julianów-Marysin-Rogi, Łagiewniki, Osiedle Wzniesień Łódzkich, Radogoszcz, and Teofilów-Wielkopolska. 50 surveys were conducted in each designated area. The research used three channels to reach respondents: (1) door-to-door research, i.e. conducting a survey at the respondent's home after establishing the main age criterion, (2) conducting street surveys in the vicinity of places frequented by older persons, such as healthcare centers, churches and market places, (3) snowball sampling, i.e. recommendations by respondents of people who may be willing to participate in the research and who meet the age criteria (neighbors, friends etc.).

\section{Results}

\subsection{Characteristics of respondents}

Consent to take part in the research was more often given by women than men: just over $69 \%$ of the interviews were conducted with women and almost $31 \%$ with men. For the purposes of the analysis, the respondents were divided into age groups. People aged 65-69 constitute the largest group (20\%), followed by those aged 75-79 (18.5\%), then those aged 60-64 (just over 17\%). Approximately one third of the research participants received a vocational education (33\%), while another third of respondents completed secondary education with school-leaving examinations (just over 29\%). Due to the demographic characteristics of the research participants, the overwhelming majority of respondents indicated a retirement pension as their main source of income (nearly $85 \%$ ). Approximately $24 \%$ of respondents declared that they live on a gross income of between 500 and 1,000 PLN. This was followed by earnings of between 1,000-1,500 PLN and 2,000-2,500 PLN (with slightly over 13 per cent in each case).

The majority of people taking part in the research share their household with another person (nearly $61 \%$ ), with just under a third of respondents living alone.

The vast majority of respondents live in multi-family housing $(73.5 \%)$. 


\subsection{Activity types and mobility ranges for people aged $60+$}

The results of the study on types of activities and ranges of mobility among those aged 60 and above indicate that:

- such people are already excluded from the majority of regular activities (Figure 3);

- within the last 4 weeks, their main daily out-of-home activity has been grocery shopping;

- more than $50 \%$ of those researched are excluded from such »higher order « activities as entertainment, culture, going to the hairdresser or beautician;

- older Bałuty residents do get involved in such activities as the 3rd age university, courses, and senior citizen clubs;

- commuting to work involves mainly the youngest age group, i.e., citizens aged 60-64 (on weekdays, approximately $1 / 3$ of them commute to work on a daily basis, with slightly below $6 \%$ commuting a few times during the week).

The study, when referring to levels of motorisation among senior citizens, indicates that:

- a vast majority (71.5\%) of those surveyed do not possess their own private car;

- among the elderly, car ownership is considerably more common for men (46\%) than for women (21\%);

- the tendency to own a car diminishes with age (Figure 4).

When we take into account the data describing the destination of trips and car ownership, it should come as no surprise that those surveyed use their private car primarily to commute to work (Table 1).

Public transport is, however, equally popular (regardless of trip motivation). Despite the fact that the percentage of trips taken on foot is relatively high, there is still quite a potential for modal shifting from trips made by private car.

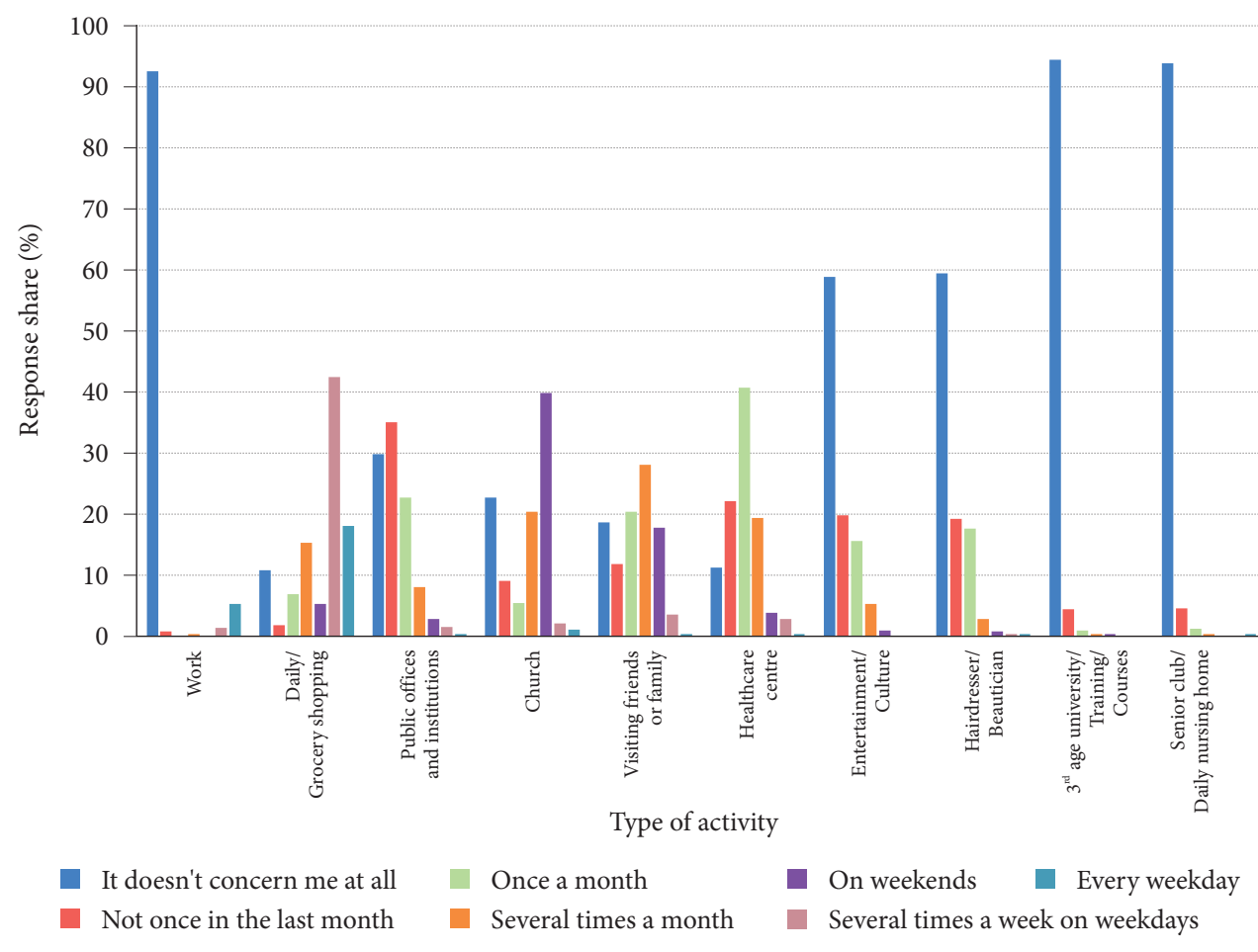

Figure 3: Frequency of activities for senior citizens. 


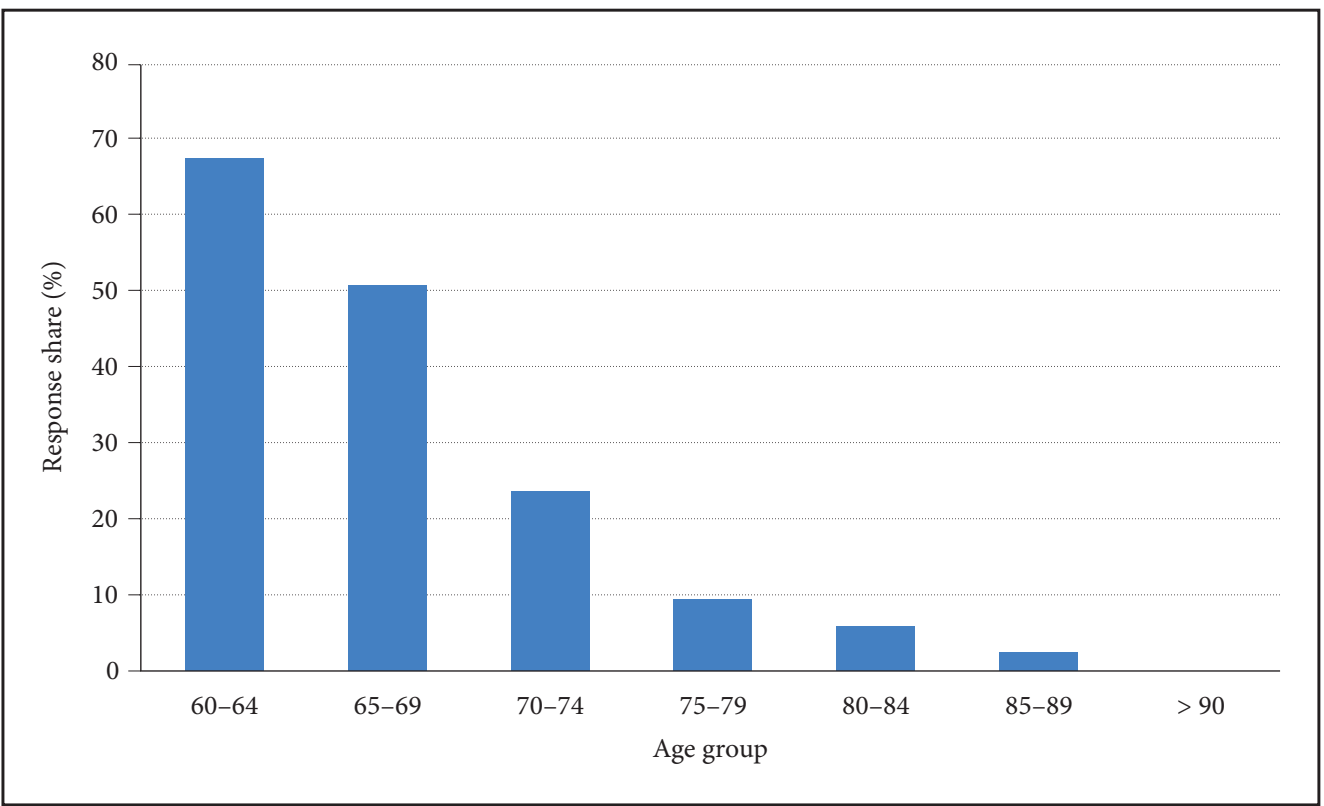

Figure 4: Car ownership versus respondent's age.

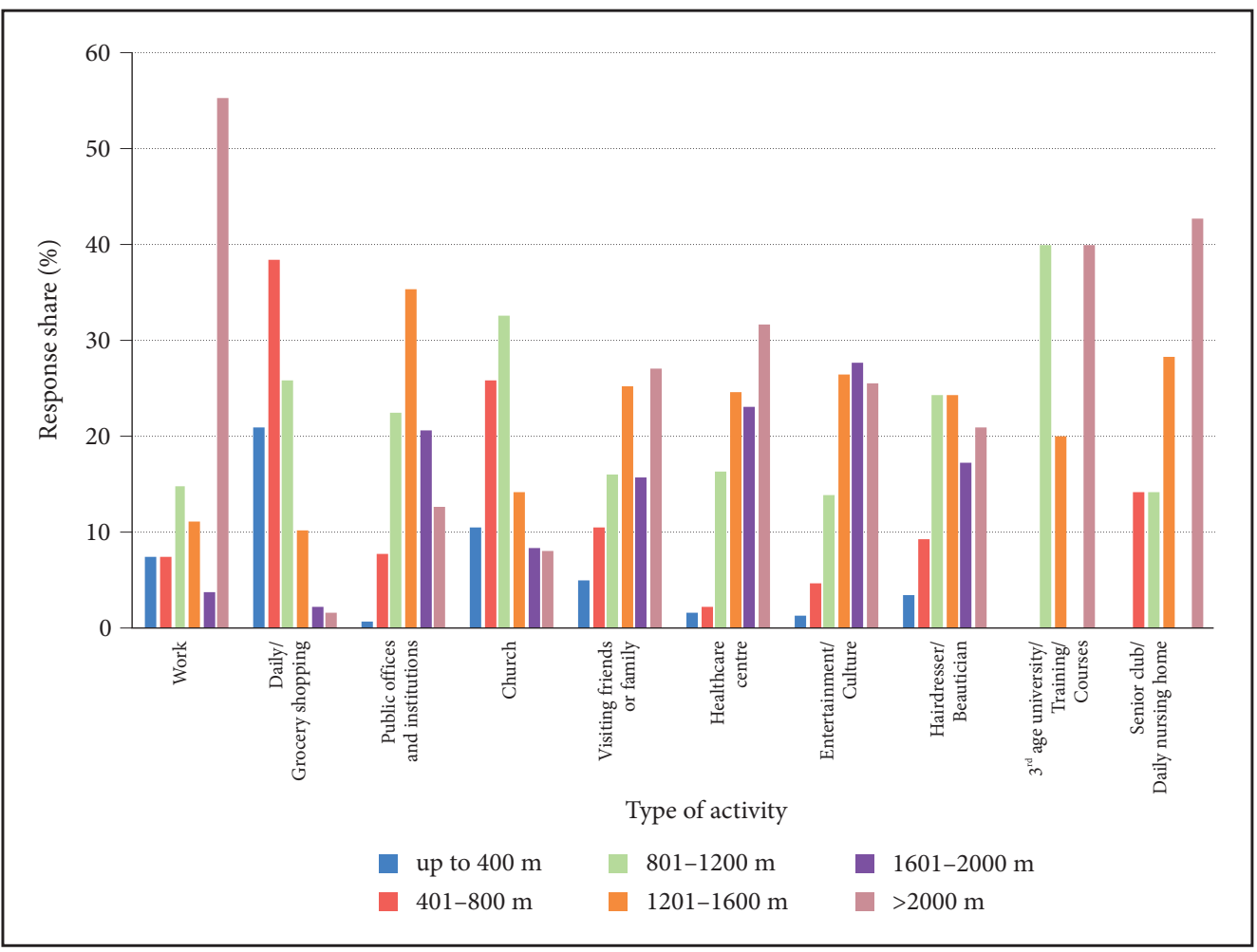

Figure 5: Travel distance versus trip motivation. 


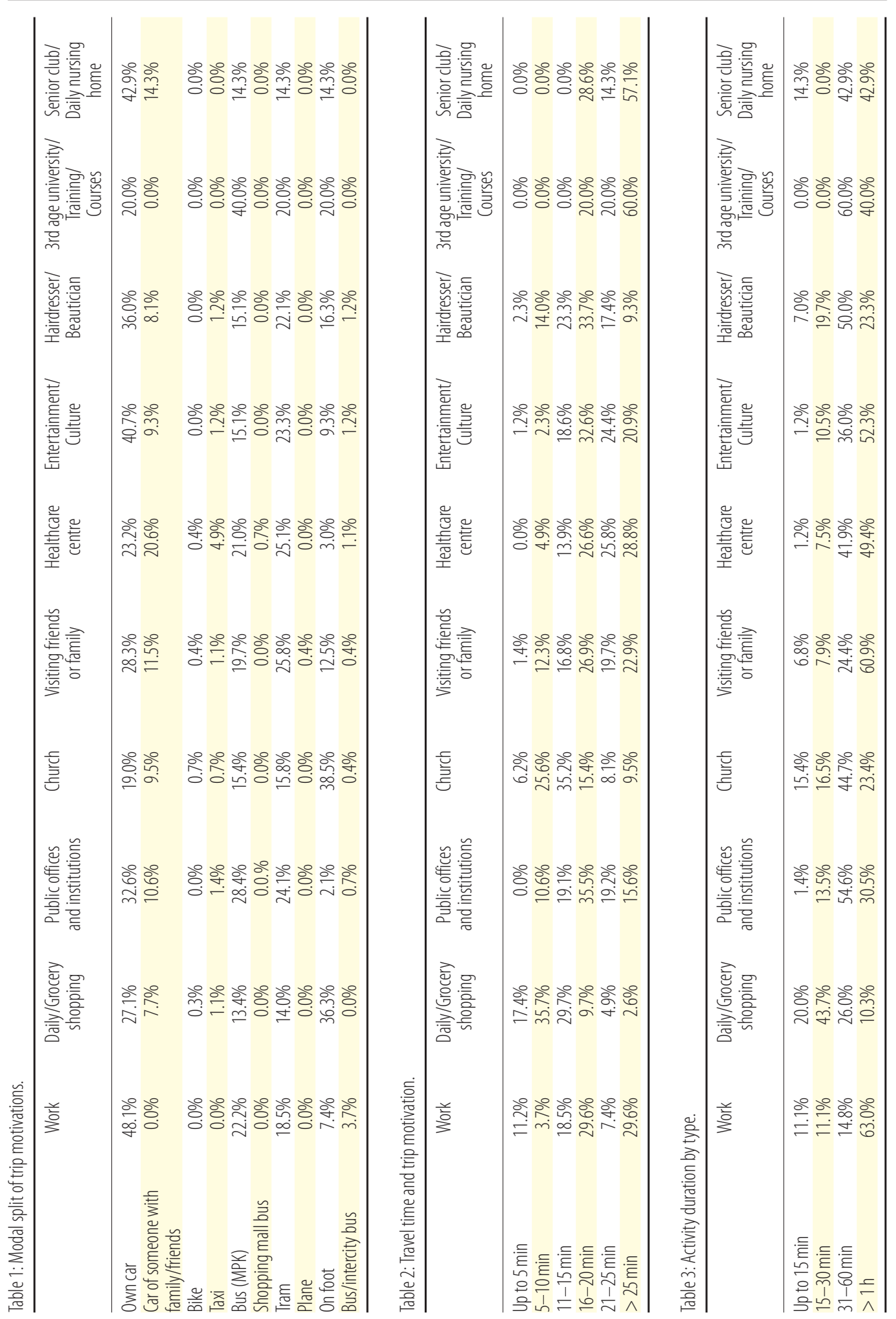


Trips taken by senior citizens usually last for over 15 minutes (Table 2), and it is particularly common for them to take up to 16-20 minutes (regardless of trip motivation).

The greatest timeframe in travel time is recorded for visits paid to family/friends and trips to healthcare centres.

The surveyed senior citizens devoted most time to commuting to work, visiting friends and family, to entertainment, and to going to healthcare centres (Table 3).

In the above four cases, duration time is over an hour, while - on average - going to public offices and institutions, and to church, as well as visiting a hairdresser/beautician takes up to an hour.

Clearly, the greatest distances are covered by senior citizens who still remain professionally active (Figure 5).

The spatial relationships between the place of residence and the destinations where senior citizens carry out their tasks (and in particular, fulfil their needs of higher order) seem to justify the still limited share of trips taken on foot within the modal split.

Over $50 \%$ of the surveyed senior citizens declared that they do not feel their mobility to be restricted in any way. The rest mentioned health as the main limiting factor (72\%), which was followed by advanced age (57\%), and inadequate adaptation of public transport vehicles to the needs of senior citizens (15\%). Financial matters, however, do not seem to pose a significant transportation obstacle. The study showed that only one in twenty senior citizens when using public transport commented on an inadequate distribution of bus and tram stops.

\section{Discussion}

The research conducted on the selected group of senior citizens shows that the reasons for daily journeys undertaken by Łódź-Bałuty's older inhabitants are likely to be shopping, going to church and visiting family and friends. It may be inferred, therefore, that above all, they choose to satisfy their basic needs. Senior citizens less often spend time outdoors than young people; they rarely go to theatres or cinemas, and consequently they are less frequently encountered in public spaces, which is also confirmed by other research (Borkowska-Kalwas 2002; Halicka and Halicki 2002; Oliwińska 2009; Kubicki 2010; Borowska-Stefańska and Wiśniewski 2019). The results of a 2016 study conducted in Łódź show that senior citizens spend their leisure time in parks/forests (24.6\%) and retail facilities (16.5\%), meeting friends (13.8\%), in the vicinity of their house/block of flats (13.2\%), and in public squares (12.8\%) (Pielesiak 2017). In addition, our research results show that together with population ageing, there is a decline in mobility levels, which is also confirmed by other research (Hanson 1977; Alsnih and Hensher 2003; Tiitta 2003). Analysis of the obtained data shows that with regard to mobility and activity, the turning point for the elderly comes between the age of 70 and 75. Up to this point "younger « senior citizens (i.e. aged 60 to 69/74) are characterized by relatively high mobility and involvement in different types of pursuits and activities. This is convergent with what can be concluded from the research conducted by Pielesiak (2017), which indicates that the elderly subjectively feel that younger senior citizens (aged 60-75) participate in urban life to a relatively substantial extent.

Noble (2000) points to the decrease in mobility with age, which notes that in addition to the decrease in the number of journeys, the distances traveled and types of transport also change. The increased opportunities to travel freely are affected by the relatively large number of people in these age groups who have access to their own car or a car belonging to somebody they live with. In addition, most of these people are already retired and usually it is the journey to work that takes most time. Unfortunately, a reduction in mobility can result in an increase in isolation, loneliness and depression (Fonda, Wallace and Herzog 2001; Windsor et al. 2007; Edwards et al. 2009; Ziegler and Schwanen 2011) which can have an impact on reducing social contacts and a deterioration of mental health and emotional wellbeing (Smith et al. 2002; Mollenkopf et al. 2004; Allen 2008; Ziegler and Schwanen 2011). A serious problem arises for the elderly when they cease to drive - an activity which is normally associated with a sense of greater independence. Research shows that although there is "life after giving up driving «, it is necessary to offer some help to older drivers (Adler and Rottunda 2006) which is particularly important among women as they more often tend to give up driving, as evidenced by various studies (Hakamies-Blomqvist and Siren 2003). Maintaining environmental justice requires the maintenance of mobility for senior citizens at as high a level as possible, 
and it should not merely entail the reactivation of their desire to be mobile (Tacken 1998). This may help reduce the aforementioned phenomenon of depression and keep the existing standards of living (Alsnih and Hensher 2003).

The significance of mobility and independence in that matter is evidenced by the research results indicating that, on the whole, senior citizens who travel more and are car or van owners evaluate the quality of their life far more positively (Banister and Bowling 2004). Moreover, relatively few respondents take advantage of the leisure or cultural facilities on offer, which may be a result of their low income and architectural and transport barriers (Błędowski and Kubicki 2009; Pielesiak 2017; Borowska-Stefańska and Wiśniewski 2019), or lack of information about current events in the vicinity, etc. The research also suggests that older people's mobility limitations result mainly from their age and health problems.

The number of elderly drivers is growing steadily among the population (Rosenbloom 2001), which stems from the base effect (each year, there are more drivers aged 60+). A perfect illustration of this phenomenon are the studies conducted in Australia, where an incremental increase in the number of (all) trips taken by car by senior citizens is recorded with a simultaneous drop in the number of trips taken by bus (Alsnih and Hensher 2003). Upwards of a third of the, relatively, younger respondents have access to a car to some extent, with most of them having their own transport. However, car use falls dramatically with age and a clear division becomes apparent: up to the age of 70, senior citizens use a car fairly often for the purposes of travelling longer distances; but then there is an increase in the number of public transport users. In general, it is beneficial for the oldest age groups to cease driving, since elderly drivers often pose a threat on the road, and the typical functional impairments associated with normal ageing and medical conditions which are usually manifested at old age often become causes of accidents (Dickerson et al. 2007). Therefore, a drop in car use should be expected with age, while use of public transport for daily journeys should increase. Yet, as it is revealed by both the research conducted in Łódź and, for instance, Sweden, public transport is described by the elderly as expensive and not particularly accessible or safe (while travelling unaccompanied), and passenger information is deemed to be poor (Mackett 2015; Pielesiak 2017; Raczyńska-Buława 2017). The elderly express a range of opinions on public means of transport, emphasising their positive and negative sides (Coughlin 2001). As indicated by Alsnih and Hensher (2003), the approach that allows us to avoid one of the most serious, negative aspect of conventional public transport (based on fixed route) is to provide an alternative in the form of a more flexible system, which may be economically viable in the evolving market conditions. The issue of public transport costs is addressed quite differently and with an intention to eliminate it as a factor that can contribute to the exclusion of senior citizens. Implementation of free-of-charge travel outside rush hours generates new trip motivations among the elderly and can even lead to the phenomenon of "Bus Roulette" (Andrews et al. 2012). In Łódź, people aged $70+$ are entitled to use public transport free of charge at any time of the day, while younger pensioners are eligible for a $50 \%$ discount.

Furthermore, the distance to stops is of considerable importance for older citizens using public transport (Carp 1988). Regrettably, this study shows that the distance to stops was assessed as poor by respondents (mainly in the case of buses). Therefore, ceasing to drive a car may have an adverse effect on the well-being of the elderly (Metz 2000; Davey 2007), because, as shown by the conducted research, it has an impact on reducing mobility. Having your own car available at any hour, provides door-to-door transport, and is a symbol of independence and autonomy (Davey 2007), and the use of public transport is not yet able to replace the car.

\section{Conclusion}

The problems of senior citizens are crucial because the population of this age group is continuously growing in number, which poses a formidable challenge at a global and local scale. The increase in this social group exercises an incremental pressure on transportation, which becomes particularly noticeable in cities. And yet, the existing research on the matter remains scarce. Studies into the mobility of the elderly ought to be conducted regularly, and their results could be utilised to create a blueprint for transport policy. Since transportation is a fundamental human need, maintenance of the mobility of the elderly at an acceptable level is crucial as it directly impacts the quality of their life. What is more, a change of motivation and mode of transport is recommended for this age group. Namely, senior citizens are advised to use public transport 
more often than before and instead of the car, while the maintenance of mobility requires the portfolio of potential destinations to be expanded so as to fill the gap created by retirement and lack of necessity to commute to work. In the course of the study, it was found that part of mobility which in the case of the elderly can be perceived as common/daily does not really fit into this category. Another observation was that despite a theoretically greater amount of spare time, senior citizens do not undertake a longer list of everyday trips than younger social groups. The patterns of mobility among the elderly and professionally inactive differ, which is evidenced by the results presented in the articles reviewed. City authorities should pay greater attention to this social group, especially with regard to public transport. This approach fits squarely into the philosophy of sustainable urban transportation, and additionally, involves the issue of intergenerational equality.

ACKNOWLEDGEMENT: The article was prepared as a part of a research project financed by the National Science Center in Poland»The daily mobility of the elderly in Lodz«, No. 2018/02/X/HS4/00378.

\section{References}

Adler, G., Rottunda, S. 2006: Older adults' perspectives on driving cessation. Journal of Aging Studies 20-3. DOI: https://doi.org/10.1016/j.jaging.2005.09.003

Allen, J. 2008: Older people and wellbeing. London.

Alsnih, R., Hensher, D. A. 2003: The mobility and accessibility expectations of seniors in an aging population. Transportation Research Part A: Policy and Practice 37-10. DOI: https://doi.org/10.1016/ S0965-8564(03)00073-9

Andrews, G., Parkhurst, G., Susilo, Y. O., Shaw, J. 2012: The grey escape: investigating older people's use of the free bus pass. Transportation Planning and Technology 35-1. DOI: https://doi.org/10.1080/ 03081060.2012 .635413

Banister, D., Bowling, A. 2004: Quality of life for the elderly: the transport dimension. Transport Policy 11-2. DOI: https://doi.org/10.1016/S0967-070X(03)00052-0

Bartosiewicz, B., Pielesiak, I. 2014: Dzienna mobilność mieszkańców małych miast Łódzkiego Obszaru Metropolitalnego. Prace Naukowe Uniwersytetu Ekonomicznego we Wrocławiu 367.

Błędowski, P., Kubicki, P. 2009: Warszawa przyjazna seniorom-lata 2010-2015. Warszawa.

Borkowska-Kalwas, T. 2002: Sposoby spędzania wolnego czasu. Starzy ludzie w Polsce. Społeczne i zdrowotne skutki starzenia się społeczeństwa. Warszawa.

Borowska-Stefańska, M., Wiśniewski, S. 2019: Mobilność codzienna osób starszych w Łodzi. Łódź.

Carp, F. M. 1988: Significance of mobility for the well-being of the elderly. Transportation in an aging society: Improving mobility and safety of older persons 2.

Central Statistical Office, 2019. Internet: https://stat.gov.pl/ (15. 10. 2019).

Coughlin, J. 2001: Transportation and Older Persons: Perceptions and Preferences. Washington. Internet: http://assets.aarp.org/rgcenter/il/2001_05_transport.pdf (15.10. 2019).

Coughlin, J. F. 2009: Longevity, lifestyle, and anticipating the new demands of aging on the transportation system. Public Works Management \& Policy 13-4. DOI: https://doi.org/10.1177\%2F1087724X09335609

Davey, J. 2007: Older people and transport: coping without a car. Ageing and Society 27-1. DOI: https://doi.org/ $10.1017 /$ S0144686X06005332

Dickerson, A. E., Molnar, L. J., Eby, D. W., Adler, G., Bédard, M., Berg-Weger, M., Classen, S., Foley, D., Horowitz, A., Kerschner, H., Page, O., Silverstein, N. M., Staplin, L., Trujillo, L. 2007: Transportation and Aging: A Research Agenda for Advancing Safe Mobility. The Gerontologist 47-5. DOI: https:/doi.org/ 10.1093/geront/47.5.578

Edwards, J. D., Perkins, M., Ross, L. A., Reynolds, S. L. 2009: Driving status and three-year mortality among community-dwelling older adults. Journals of Gerontology series A 64A-2. DOI: https://doi.org/10.1093/ gerona/gln019

El-Telbani, J. 1993: Transport problems of disadvantaged people: case studies of the elderly in four areas of Sheffield. Ph.D. thesis, University of Sheffield. Sheffield.

Fonda, S. J., Wallace, R. B., Herzog, A. R. 2001: Depressive Symptoms Among Older Adults. Journal of Gerontology: Social Sciences 56B-6. DOI: https://doi.org/10.1080/13607863.2012.747078 
Hakamies-Blomqvist, L., Siren, A. 2003: Deconstructing a gender difference: Driving cessation and personal driving history of older women. Journal of Safety Research 34-4. DOI: https://doi.org/10.1016/ j.jsr.2003.09.008

Halicka, M., Halicki, J. 2002: Integracja społeczna i aktywność ludzi starszych. Polska starość. Gdańsk.

Hanson, P. 1977. The activity patterns of elderly households. Geografiska Annaler: Series B, Human Geography 59-2. DOI: https://doi.org/10.1080/04353684.1977.11879425

Haustein, S., Siren, A. 2015: Older people’s mobility: Segments, factors, trends. Transport Reviews 35-4. DOI: https://doi.org/10.1080/01441647.2015.1017867

Hildebrand, E. D. 2003: Dimensions in elderly travel behaviour: A simplified activity-based model using lifestyle clusters. Transportation 30-3. DOI: https://doi.org/10.1023/A:1023949330747

Hjorthol R. J., Levin, L., Sirén, A. 2010: Mobility in different generations of older persons: The development of daily travel in different cohorts in Denmark, Norway and Sweden. Journal of Transport Geography 18-5. DOI: https://doi.org/10.1016/j.jtrangeo.2010.03.011

Kałuża-Kopias, D. 2014: Specyfika przemieszczeń wewnętrznych osób starszych w Polsce. Studia Demograficzne 2-166.

Kaplan, G. A. 1995: Where do shared pathways lead? Some reflections on a research agenda. Psychosomatic Medicine 57.

Kim, S. 2011: Transportation alternatives of the elderly after driving cessation. Transportation research record 2265-1. DOI: https://doi.org/10.3141/2265-19

Komornicki, T. 2011: Przemiany mobilności codziennej Polaków na tle rozwoju motoryzacji. Warszawa.

Kubicki, P. 2010: Ubóstwo i wykluczenie społeczne osób starszych. Ekspertyza przygotowana w ramach projektu EAPN Polska - razem na rzecz Europy Socjalnej. Warszawa.

Labus, A. 2013. Odnowa miast a starzejące się społeczeństwa europejskie na wybranych przykładach. Problemy Rozwoju Miast 2.

Li, H., Raeside, R., Chen, T., McQuaid, R. W. 2012: Population ageing, gender and the transportation system. Research in transportation economics 34-1. DOI: https://doi.org/10.1016/j.retrec.2011.12.007

Mackett, R. 2015: Improving accessibility for older people - Investing in a valuable asset. Journal of Transport and Health 2-1. DOI: https://doi.org/10.1016/j.jth.2014.10.004

Mercado, R., Páez, A. 2009: Determinants of distance traveled with a focus on the elderly: a multilevel analysis in the Hamilton CMA, Canada. Journal of Transport Geography 17-1. DOI: https:/doi.org/ 10.1016/j.jtrangeo.2008.04.012

Metz, D. 2003: Transport policy for an ageing population. Transport Reviews 23-4. DOI: https://doi.org/ $10.1080 / 0144164032000048573$

Metz, D. H. 2000: Mobility of older people and their quality of life. Transport policy 7-2. DOI: https://doi.org/ 10.1016/S0967-070X(00)00004-4

Model zrównoważonego transportu zbiorowego w Łodzi 2020+, 2019. Internet: http://zdit.uml.lodz.pl/files/ konsultacje_spoleczne/mztt_6d35f82e.pdf (15. 10.2019).

Mollenkopf, H., Marcellini, F., Ruoppila, I., Széman, Z., Tacken, M., Wahl, H.-W. 2004: Social and behavioural science perspectives on out-of-home mobility in later life: findings from the European project MOBILATE. European Journal of Ageing 1-1. DOI: https://doi.org/10.1007/s10433-004-0004-3

Noble, B. 2000: Travel characteristics of older people. Transport Trends 2000. London.

Oliwińska, I. 2009: Style życia współczesnych Polaków na przedpolu starości. Przygotowanie do starości. Polacy wobec starzenia się. Warszawa.

Páez, A., Scott, D., Potoglou, D., Kanaroglou, P., Newbold, K. B. 2007: Elderly mobility: demographic and spatial analysis of trip making in the Hamilton CMA, Canada. Urban Studies 44-1. DOI: https://doi.org/ 10.1080/00420980601023885

Pielesiak, I. 2017: Participation in urban life and obstacles for mobility of the elderly in Łódź. Space - Society Economy 20. DOI: https://doi.org/10.18778/1733-3180.20.06

Raczyńska-Buława, E. 2017: Mobilność osób starszych. Dlaczego nie transport publiczny? TTS Technika Transportu Szynowego 24.

Roorda, M. J., Páez, A., Morency, C., Mercado, R., Farber, S. 2010: Trip generation of vulnerable populations in three Canadian cities: a spatial ordered probit approach. Transportation 37-3. DOI: https://doi.org/ 10.1007/s11116-010-9263-3 
Rosenbloom, S. 2001: Sustainability and automobility among the elderly: An international assessment. Transportation 28-4. DOI: https://doi.org/10.1023/A:1011802707259

Rosenbloom, S. 2004: Mobility of the Elderly. Transportation in an Aging Soceity. Washington.

Saboor, M., Sum, S., Sahaf, R., Pourghasem, M. 2015: The Internet use in elderly people. Medicinski Glasnik/ Medical Gazette 20-56.

Schwanen, T., Dijst, M., Dieleman, F. M. 2001: Leisure trips of senior citizens: determinants of modal choice. Tijdschrift voor economische en sociale geografie 92-3. DOI: https://doi.org/10.1111/1467-9663.00161

Schwanen, T., Páez, A. 2010: The mobility of older people: an introduction. Journal of Transport Geography. 18-5. DOI: https://doi.org/10.1016/j.jtrangeo.2010.06.001

Sierpiński, G. 2012: Zachowania komunikacyjne osób podróżujących a wybór środka transportu w mieście, Prace Naukowe Politechniki Warszawskiej. Transport 84.

Smith, J., Borchelt, M., Maier, H., Jopp, D. 2002: Health and well-being in the young old and oldest old. Journal of Social Issues 58-4. DOI: https://doi.org/10.1111/1540-4560.00286

Stjernborg, V., Wretstrand, A., Tesfahuney, M. 2015: Everyday life mobilities of older persons - a case study of ageing in a suburban landscape in Sweden. Mobilities 10-3. DOI: https://doi.org/10.1080/ 17450101.2013.874836

Tacken, M. 1998: Mobility of the elderly in time and space in the Netherlands: An analysis of the Dutch National Travel Survey. Transportation 25-4. DOI: https://doi.org/10.1023/A:1005042614848

Taylor, Z. 1999: Przestrzenna dostępność miejsc zatrudnienia, kształcenia i usług a codzienna ruchliwość ludności wiejskiej. Wrocław.

Tiitta, S. 2003: Identifying elderly people's needs for communication and mobility. Include 7.

Windsor, T. D., Anstey, K. J., Butterworth, P., Luszcz, M. A., Andrews, G. R. 2007: The role of perceived control in explaining depressive symptoms associated with driving cessation in a longitudinal study. The Gerontologist 47-2. DOI: https://doi.org/10.1093/geront/47.2.215

Wyszomirski, O. 2008: Transport miejski. Ekonomika i organizacja. Gdańsk.

Ziegler, F., Schwanen, T. 2011: »I like to go out to be energised by different people«: an exploratory analysis of mobility and wellbeing in later life. Ageing \& Society 31-5. DOI: https://doi.org/10.1017/S0144686X10000498 